\title{
Nursing care in fever: Assessment and implementation
}

\section{Märtha Sund-Levander RN MSc Lis-Karin Wahren CLT, Ph D Elisabeth Hamrin RN BM DMSc Professor Emeritus}

ABSTRACT

Nursing care of a febrile patient should be guided by a theoretical framework and scientific knowledge. The aim of this study was

to describe nurses' assessment and implementation strategies for adult, febrile patients. Eight nurses and four physicians from four different clinics were interviewed.

The clinics were neurosurgery intensive care, intensive care, surgery and geriatric rehabilitation. An interview guide with themes theoretical knowledge and personal opinion about fever, assessment of patient needs, implementation of nursing care and methods for monitoring body temperature, constituted the framework for the interviews. The data was analysed by content analysis. The results showed that traditional methods of lowering elevated temperature, and fever regarded as synonymous to elevated body temperature and an expression of a negative process, still had great influence in nursing care. The basic approach for assessment and implementation of nursing care in fever seemed to be based on tradition and routines within each clinic, and personal beliefs. The conclusion is that

methods of lowering elevated temperature, when necessary, have to be questioned, and carried out in a way which prevents

shivering. The assessment of measuring body temperature ought to be studied more in relation to age and place of measure-

ment.

Keywords: Fever, nursing care, assessment, implementation.

\section{Introduction}

Nursing care of a febrile patient is a natural and essential task for nurses as it effects the patient's need of physiological and psychological support. The traditional view of fever as a sign of illness, associated with negative consequences for the body, and fever as strictly $38.0^{\circ} \mathrm{C}$ or more, is not enough to guide the nurse in her/his assessment and implementation concerning a febrile patient. The actions should be guided by scientific knowledge about the concept of fever, thermoregulation during fever, antipyresis and methods for measuring body temperature, combined with assessment of the individual patient. The aim of this study was to describe nurses' assessment and implementation strategies with respect to adult, febrile patients in the light of a theoretical framework and knowledge.

\section{The concept of fever}

Fever has two dimensions: immunological effects, i. e. defending the body against intruders, and elevated body temperature. Fever is mediated by the cytokines released from activated leukocytes and other cell types in the acute-phase response $(1,2)$. The cytokine Interleukin-1 (Il-1) promotes sleep, analgesia and reduces appetite, but the prominent function is to mediate fever. Il-1 is thought to influence the synthesises of prostaglandin E2 (PgE2), which elevates the set point in the hypothalamus. When the alien is eliminated or PgE2 is blocked by antipyretics, the synthesising of PgE2 decreases and the set point readjusts to euthermic range (1). Fever of $>41^{\circ} \mathrm{C}$ is very unusual (3), which is believed to be caused by immunosuppression by bodily produced substances e. $\mathrm{g}$. ACTH and glucocorticoid $(2,4)$ Even if elderly individuals often present atypical symptoms in infections, including absence of fever, compared to younger individuals (5), the traditional definition of fever as more than $38.0^{\circ} \mathrm{C}$ still persists (6). Elevated body temperature disturbs bacterial adherence and protein synthesis, increases bacterial susceptibility to antibiotics (7), reduces plasma iron concentration to suppress bacterial growth (8) and stimulates B-and T-lymphocytes (1).

\section{Thermoregulation during fever}

During fever, thermoregulatory mechanisms function normally (9) and the individual circadian rhythm of normal body temperature is maintained (1). Fever runs a dynamic course of three phases starting with the chill phase. The discrepancy between the new set point range and the existent temperature triggers heat production and conserves heat, i. e. increased metabolism and vasoconstriction. The next phase, the plateau phase, follows when body temperature maintains the elevated set point level. In the third phase «overshot «, where the set point range of rising body temperature is exceeded, triggers heat loss mechanisms, i. e. radiation, conduction, convection and evaporation. This course makes the temperature curve dynamic unlike the linear curve of hyperthermia, which is due to dysfunction in the hypothalamus (10).

\section{Antipyresis}

At the turn of the century, a cool environment, exposure of the patient's skin and sponge baths were medical recommendations $(11,12)$. Antipyretic drugs were introduced during the late 1800 s and have since been commonly used (13). Recent research has found that antipyretic drugs are as effective alone as used together with surface cooling to lowering temperature in fever (14). One side-effect of antipyretic drugs is that they can hide the effect of treatment and delay correct medi- cation (3). If cooling is necessary, ice water or cold water immersion should be avoided (15). Surface cooling should always be combined with antipyretic drugs to prevent shivering (10). Covering the extremities with cloth before lowering the temperature by cooling, also prevents shivering $(16,17)$

\section{Monitoring body temperature}

Frequent monitoring and assessment of body temperature gives information about pattern, duration and course of fever. The aim of measuring body temperature in clinical practice is to estimate the deep body temperature, the core temperature. The alternatives described for measuring body temperature are a. pulmonalis, the tympanic membrane, the oesophagus, the mouth, the axilla, the rectum or in the urinary bladder. As the result depends on vasomotoric activity, the site of measuring and diurnal variations, no one temperature characterises the thermal status of the body (18). Samples et al (19) identified 5 P.M. to 7 $\mathrm{PM}$ as the best time for detecting fever.

\section{Methods}

The study was supported by the director of each clinic. The respondents were given oral information and gave their consent to participation.

To describe some aspects of nursing care in fever in relation to a theoretical concept of fever a qualitative approach was chosen. The data was collected by interviews. An interview guide with themes constituted the framework for the interviews. The themes were theoretical knowledge about the concept of fever, assessment of patient needs and implementation strategies of nursing care, including methods for monitoring body temperature. A literature review constituted the framework for the theme theoretical know- 
ledge. The themes assessment of patient needs, implementation of nursing care and methods for monitoring body temperature were selected to explore aspects of the nursing process. An interview guide gave the opportunity to catch the subject's experiences, without deciding beforehand the perspective with strict questions. The interviewer could freely ask for further explanation and thereby enhance the richness of the contents in the data. As the interview guide structured the collection of data and the analysis of data simultaneously, it therefore also strengthened credibility and truth values (20).

\section{Material}

The study was conducted in a neurosurgery intensive care unit (NICU) at a university hospital, in an intensive care unit (ICU), a surgery clinic (SC) and a clinic for geriatric rehabilitation (GR) at another hospital in the south of Sweden. One nurse with more experience (more than ten years since graduation from nursing school) and one nurse with less experience (less than three years since graduation from nursing school) were selected by stratified random sampling from each clinic, $n=8$. As the medical aspect is important for nursing implementation strategies, one physician from each clinic was interviewed about treatment strategies in fever, $n=4$. One physician denied and another physician was selected from the same clinic.

\section{Procedure}

The interviews were performed by one and the same person (M $\mathrm{S}-\mathrm{L}$ ). Two nurses were interviewed before the main study, and gave suggestions on improvement of the order of the themes. The respondents were contacted by telephone and they decided themselves time and place for the interview. The interviews were performed in seclusion, and lasted for 30-60 minutes. As an interview guide constituted the framework, the interview became a dialogue between the interviewer and the respondent. The dialogue allowed the respondent to express his/her own opinion and experience. Each interview was recorded and was then transcribed. The tapes were destroyed after comparison of tape and transcription.

\section{Analysis of data}

With an interview guide, answers from different people could be grouped by topics from the guide, as relevant data was found in different places in each text. Therefor the interview guide also constituted a framework for the data analysis. The texts were analysed by content analysis, which means identifying, coding and categorising the primary pattern in the data $(20$, 21). The analysis was performed in the following manner: Each interview was read through several times to get an overview, and a sense, of the content. The next step was to structure the data according to the themes in the interview guide. This was made by notes in the margins and then by cutting the text into pieces. The data was then categorised, by putting the pieces together, to classify units of content. Finally units of contents were related to the nurses with more experience and to the nurses with less experience respectively, and the nurses' answers related to the physicians' answers. The classification resulted in units of contents both within the themes and into new dimensions.

\section{Results}

Theoretical knowledge about the concept of fever.

The nurses related fever as a sign of ongoing illness in the first place, but also as a defence against infection without further explanation, apart from two nurses from different clinics, who had very good knowledge of the role of cytokines and fever in the immune defence. Personal opinion appeared to be more important than theoretical knowledge in the nurses' opinion of fever as a phenomenon: «It is so to speak not healthy to have fever» and «Fever is, in fact, a sign of health». Postoperative fever was generally interpreted as a norma reaction not related to infection. The majority of the nurses defined fever as more than $38^{\circ} \mathrm{C}$ and temperatures of more than $39^{\circ} \mathrm{C}$ as high fever. The nurses in GR did not in speech consider age when assessing fever, but in practice this was a part of their judgement.

\section{Assessment of patient needs}

The nurses described both physiological and psychological aspects, i. e. patient experience, in their assessment of the patients need. They also considered basic illness, degree of elevated temperature, ongoing antibiotics and whether the patient was awake or unconscious, but their assessment emphasised nutrition and fluid supply. Nurses with more experience stressed the risk of complications and physiological consequences: » Check the urine ...send a culture.... take blood samples of course... nutrition and fluid and kidneys, one has to think about all that». The tendency among nurses with less experience were to stress the patient's experience of illness and their desires concerning what was pleasant:»... They get warm and do not feel well Then there is risk for decubitus, they perspire and remain in bed and one has to make the bed often. They need parenteral nutrition" and «The patient decides about his/her own comfort».

\section{Implementation of nursing care}

The nurses generally stated actions with regard to lowering elevated temperature because of increased oxygen demands and potential damage to neurologic tissue. The actions were also emphasised in the conditions of an impaired circulatory system. Antipyretic drugs, undressing, sponging with water and cool surroundings were common actions described. Cooling with alcohol, sometimes combined with a fan, was also outlined. Which actions the nurse preferred depended on her/his own opinion as there were no guiding routines: «I think it is much up to me, who takes care of the patient to decide». One nurse with long experience established that «you do what you have always done».

\section{Monitoring body temperature}

The routines and methods of measuring body temperature differed between the clinics, but not within the clinic. One clinic used axillary monitoring and the other three tympanic measurement. Several nurses were not sure about how to assess the value, especially the tympanic measurement: «We repeat the procedure several times; we have chosen the higher value. It feels more secure». Temperature was measured twice a day, morning and afternoon, and if necessary in the evening, as always: «We have always had those routines, as far as I know since the 60s. But I don't know why, actually».

\section{Routines within the clinic}

When the nurses' and the physicians' answers were compared, the importance of the tradition and routines within the clinic appeared. In NICU fever was related only to infection or cerebral injury and associated with a negative process. Temperature $>38^{\circ} \mathrm{C}$ 
was routinely treated irrespective of the presence of increasing intracranial pressure or not: «If the temperature is more than $38^{\circ} \mathrm{C}$ of course you give antipyretics». In the ICU fever was related to a sign of warning in the first place. Temperature of more than $39^{\circ} \mathrm{C}$ was associated with risk of physiological complications. The patients were assessed individually and the necessity of avoiding shivering was stressed: «If they (patients) do not feel badly I do not usually give them anything». In the SC fever was regarded as a normal reaction which increases the body defence against alien substances: «So we do not treat them in any special way.... give them an extra blanket if they want to». Antipyresis was of interest if the temperature increased to about $40^{\circ}-41^{\circ} \mathrm{C}$, or if circulatory complications arose. In GR both physicians and nurses considered $38^{\circ} \mathrm{C}$ as borderline but adjusted assessment and actions to elderly people's reactions. The patient's personal experience was more important than the degree of fever when considering investigation and actions: «Generally you can say that the patients feelings are more important for my decision about actions».

\section{Discussion}

The aim of this study was to describe the nurses' assessment and implementation strategies with respect to adult febrile patients in the light of a theoretical framework and knowledge. The choice of a qualitative approach impaired transferability, compared with a quantitative study, but enhanced the richness of the data and the understanding of nursing care in fever. The results can be used as a guide for further studies.

Fever is generally related to infection or inflammation in nursing literature (10). This was supported in this study, in that there were deficiencies in the nurses' knowledge, which are of importance for their assessment and implementation. The nurses related fever as a sign of ongoing illness in the first place and not to positive effects which can be interpreted as a lack of knowledge about the immunological effects of fever. In conditions of severe head injury, it is necessary to lower the elevated temperature because of accelerated cerebral metabolism. But the belief that too high a fever can cause neurogenic damage in other conditions can be elucidated as a lack of knowledge about physiological feedback mechanisms in fever, and about the difference between fever and hyperthermia. Hence, there is a risk that fever is considered as the origin rather than the response to an illness, which can lead to the belief that lowering the temperature improves the treatment, especially when the patient is critically ill. Cooling of the skin during the chill or plateau phases can, for example, provoke shivering. Fever accelerates the metabolism 10-12\% for each degree $\mathrm{C}$, but the aerobic activity during shivering increases oxygen consumption as much as $400 \%$ (9). One instant of shivering can consequently be more strenuous for the heart and circulation than a few days of $39^{\circ} \mathrm{C}$. It is probably also more easier to predict and supply the patients need of nourishment, fluid and physical and psychological comfort when the temperature is at a steady level.

The fact that modifying the rate of heat loss and restoring heat during the chill phase, reduces the need of muscle activity and prevents shivering $(16,17)$, was not expressed by the nurses in this study. Several nurses expressed uncertainty about temperaturemeasuring methods and assessment of values, which increases the risk of incorrectly decided actions or delay of necessary actions.

It is interesting to notice that the more technical the care was, the greater was the emphasis on degree of temperature and antipyresis. The less technical, the greater the flexibility in nursing care. But fever was still considered as $38.0^{\circ} \mathrm{C}$ or more, which can lead to delays in diagnosis and treatment of infections, especially in the elderly.

The nurses described both physiological and psychological aspects in their assessment, which can be interpreted as an effort to include both science and knowledge in nursing care. However, related to experience, they emphasised differently physiological and psychological aspects in their assessment. One explanation may be varying periods of education.

Assessment and implementation in nursing care were not clearly separated in the nurses' descriptions. This can be explained as though nursing care in fever is still more related to doing than formulating goals, perform and evaluate. There were, however, no differences in implementation related to experience among the nurses. The latter can be due to imitation and acclimatisation of traditional routines in the clinic.

The actions, described by the nurses, are very similar to those recommended at the beginning of this century $(11,12)$. This also corresponds with Holzclaw (10), who draws attention to the fact that nursing literature generally recommends antipyretic drugs and cooling without further details, and that few changes in nursing actions in fever have been made during the last century.

\section{Conclusion}

Traditional methods of lowering elevated temperature and fever, regarded as synonymous to elevated body temperature and an expression of a negative process, still had great influence in nursing care in this study. The basic approach for assessment and implementation of nursing care in fever seemed to be based on tradi- tion and routines within each clinic, and personal beliefs. Methods of lowering elevated temperature, when necessary, have to be questioned, and carried out in a way which prevents shivering. The assessment of measuring body temperature ought to be studied more in relation to age and place of measurement.

\section{Akseptert for publisering} 15.04.1998

Märtha Sund-Levander RN MSc ${ }^{1}$ Lis-Karin Wahren CI.T, $\mathrm{Ph} \mathrm{D}^{2}$ Elisabeth Hamrin RN BM DMSc, Professor Emeritus ${ }^{3}$

\section{Faculty of Health Sciences:}

Department of Medicine and Care Linköping University S-581 83 Linköping Sweden.

1 Division of Physiology

2 Division of Pharmacology

3 Division of Nursing Science

Correspondence: Märtha SundLevander, Södergatan 11 S-573 39 Tranås, Sweden Telephone: 46 - 381 - 35029 , Fax: $46-381-35033$

\section{References}

1. Dinarello CA, Cannon JG, Wolff SM. New concepts on the pathogenesis of fever. Reviews of Infectious Diseases 1988; 10 168-90.

2. Gottschall PE. eds. Infectious disease, Interleukin-1 and central nervous system. Journal of the Florida Medical Association 1993; 80: 127-29.

3. Styrt B. 1990. Antipyresis and fever. Archives of Internal Medicine 1993; 1589-97.

4. Cunningham ET Jr, De Souza EB. Interleukin 1 receptors in the brain and endocrine tissues. Immunology Today 1993; 14: 171-6. 
5. Castle S, Yeh M, Toledo S, et al. Lowering the temperature criterion improves detection of infections in nursing home residents. Aging: Immunology and Infections Diseases 1993; 4: 67-75.

6. Mackowiak PA, Wasserman S, et al. A clinical appraisal of $98.60 \mathrm{~F}$, the upper limit of the normal body temperature, and other legacies of Carl Reinhold August Wunderlich. JAMA 1992; 268: 1578-80.

7. Mackowiak PA, Marling-Cason M, Cohen RL. Effects of temperature on antimicrobial susceptibility of bacteria. The Journal of Infectious Diseases 1982; 145: 550-53.

8. Bernheim HA, Block LH, Atkins E. Fever: Pathogenesis, pathophysio- logy and purpose, basic review. Annals of Internal Medicine 1979; 91: 261-70.

9. Guyton A C. Body temperature, temperature regulation and fever. In Textbook of Medical Physiology. 8th ed. Philadelphia: W. B. Saunders Company, 1991: 797-808.

10. Holzclaw B J. The febrile response in critical care: State of the science. Heart and Lung 1992.; 21 : 482-501.

11. Den Tillförlitlige Husläkaren. Stockholm :E. W. Sundkvists förlag, 1891.

12. Berg H. Feber. Läkarbok. 3rd ed. Göteborg: Nordiska förlags AB, 1924.
13. Clark W G. Antipyretics. In: Mackowiak, P. et al., eds. Fever: Basic Mechanisms and Management. New York: Raven Press, 1991: 297-340.

14. Morgan S P. A comparison of three methods of managing fever in the neurologic patient. Journal of Neuroscience Nursing 1990; 22: 19-24.

15. Harchelroad F. Acute thermoregulatory disorders. Geriatric Emergency Care 1993; 9: 621-39.

16. Abbey J C, Close L. A study of control of shivering during hypothermia. Abstract. The Nursing Clinics of North America 1979; 12: 2-3.

17. Holtzclaw B J. Control of febril shivering during Amphotericin B therapy. Oncology Nursing Forum 1990; 17: $521-524$
18. Mackowiak P A. Clinical thermometric measurements. In: Mackowiak P. Eds. Fever: Basic Mechanisms and Management. New York: LippincottRaven, 1997: 27-33.

19. Samples F, Van Cott M L, Long C, et al. Circadian rhythms: basis for screening for fever. Nursing Research 1985; 34: 377-379.

20. Patton M Q. Qualitative Evaluation and Research Methods, 2nd ed. London: SAGE Publications Ltd, 1990

21. Polit F, Hungler P. Nursing Research Principles and Methods. 3rd ed. Philadelphia: JB Lippincott Company, 1987.

\section{Nordisk konferanse om toppledelse av sykepleietjenesten}

\section{- funksjon, organisering, kompetanse}

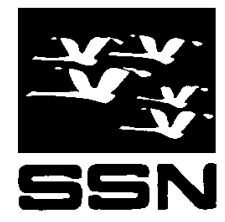

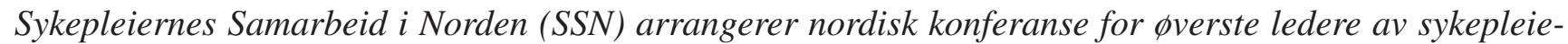
tjenesten i sykehus og primarhelsetjenesten 17.-19. mars 1999 på Hótel Saga, Reykjavik, Island

Konferansen skal bl. a.

- belyse aktuelle utfordringer/utmaninger som toppledere av sykepleietjenesten i de nordiske land står overfor

- fokusere på sykepleieleders framtidige kompetanse og funksjon

- fokusere på endringsledelse og konsekvenser for sykepleietjenesten

Konferansen annonseres i september 1998.

For ytterligere informasjon, kontakt

Sykepleiernes Samarbeid i Norden, Postboks 2681 St. Hanshaugen, N-0131 Oslo Norge

Tlf. +47220433 04/+4722383768 - Faks +4722380230

Mail: marit.helgerud@ nosf.no - eller kontakt din sykepleierorganisasjon 